\title{
Innovation in Services: A Literature Review Rabeh Morrar
}

\author{
"The increasingly prominent role being played by") \\ service activities in productive systems have \\ combined to make innovation in the service \\ sector an issue of great importance.
}

\author{
Faiz Gallouj \\ Professor of Economics
}

\begin{abstract}
The article reviews the literature relevant to innovation in services, which has flourished since the 1990s. We discuss the definition of service and to what extent the characteristics of service output have influenced the conceptualization of innovation in services. Then, based on the literature review, we develop a conceptual framework for innovation in service sector, which classifies innovation in service sector into three main approaches: i) assimilation, where innovation in the service sector is assimilated from innovation in manufacturing sector; ii) demarcation, which differentiates innovation in service sector from the traditional conceptualization of innovation in manufacturing sector; and iii) synthesis, which aggregates both assimilation and demarcation approaches within a common conceptual framework. We discuss the relationship between innovation in services and economic performance using productivity and employment as two indicators of performance.
\end{abstract}

\section{Introduction}

Awareness of the importance of service innovation as an engine for the economic growth is a recent phenomenon. Previously, services were considered as noninnovative activities, or innovations in services were reduced to the adoption and use of technologies. The innovation literature was focused on the manufacturing sector, technological product development, and process innovation, and thus, innovation in services was addressed from a manufacturing perspective. Indeed, the corresponding literature "assimilated services within the consolidated framework used for manufacturing sectors and manufactured products" (Gallouj \& Savona, 2009). The risk of such a bias towards manufacturing is the underestimation of innovation in services and its effects, because innovation in services includes invisible or hidden innovations that are not captured by the traditional indicators of innovation in the manufacturing sector.

However, the traditional approach has been increasingly challenged, mainly because the underestimation of the dynamics of the service sector was seen as incon- sistent with the rise of the service economy, which now accounts for nearly $70 \%$ of gross domestic product and employment in member countries of the Organisation for Economic Co-operation and Development (OECD, 2005). Accordingly, the discussion about innovation in services should be extended beyond the traditional (technological) perspective.

A number of studies have shed light on the specificities of innovation in services beyond the traditional biased point of view, which constrained it to the adoption and use of technology (Gallouj \& Weinstein 1997; Sundbo \& Gallouj, 1999; Tether, 2005). These studies take into account the main characteristics of the service product its intangibility, its co-production, and its co-terminality - which makes it efficient to define innovation in services.

The objective of this article is to review the extant literature on service innovation in order to identify and evaluate different models of the innovation process in services. The article also aims to show how the unresolved issues relative to the definition of service output have contributed to the underestimation of the per- 


\section{Innovation in Services: A Literature Review}

\section{Rabeh Morrar}

formance of service innovation in terms of productivity and employment. First, the characteristics that are important for defining and measuring innovation in services are discussed. Next, the main theoretical perspective mobilized in the literature to account for innovation in services is presented. This discussion addresses the main theoretical inferences associated with each perspective accompanied with a survey of the most important pertinent application in each perspective. Finally, we discuss the relationship between innovation in services, including productivity and employment as indicators of economic performance.

\section{Defining Service Output}

The characteristics of services have largely been neglected by the innovation literature. There is a particular analytical problem of the definition of service output, which reflects on the definition of service innovation. When analyzing service innovation, scholars have merely analytical tools designed for manufacturing within the traditional technological view of innovation. This approach has led to the misunderstanding and the underestimation of innovation activities in services. Gallouj and Savona (2009) argue that it has also led to a wrong conclusion that innovation in services has a relatively small effect on economic performance in terms of productivity and value added, compared to innovation in manufacturing

Therefore, a clear definition of services and their characteristics is a key factor for the correct measuring of innovation output in services and the estimation of the real economic effect of services. However, "the study of services innovation immediately poses the question of how a 'service' should be defined" (DTI, 2007). Service production is an action, or a treatment protocol, that leads to a change of state, not the creation of a tangible good (Gallouj, 1998). Because of its fuzzy nature or intangibility, its heterogeneity and unstable character, a service is difficult to define, and therefore it is also difficult to measure its output and productivity (Melvin, 1995).

Arriving at a definition of a service is useful before discussing the problem of defining innovation in the service sector and measuring the productivity impact of innovation on services. However, there is no consensus today among economists about the theoretical characterization of service activities and their output (i.e., "services") (Gadrey, 2000). Therefore, this section of the article sets out to discuss, from a critical perspective, the most prominent arguments about the distinctions between goods and services, with a focus on the definition of services.

Early definitions of services were based on technical criteria derived from classical economists. Three main definitions were adopted by those favouring a technical characterization. The first definition, advanced by Smith (1776) and Say (1803), views a service as a product that is consumed in the instant of production. The second definition, pioneered by Singelmann (1974) and Fuchs (1968), takes the notion of co-production, in other words, the interaction between consumer and producer in producing services. The third approach describes services as non-storable and non-transportable, which distinguishes services from goods (Stanback, 1980).

Hill (1977) introduced the most widely cited definition of services: "a change in the condition of a person, or a good belonging to some economic unit, which is brought about as a result of the activity of some other economic unit, with the prior agreement of the former person or economic unit". With this definition, Hill sought "to set forth a characterization of 'service situations' and of their outcomes that is both socio-technical and more synthetic" (Gadrey, 2000). Gadrey (2000) expanded Hill's definition by putting forward what is known as the "service triangle". In this view, "a service activity is an operation intended to bring about a change of state in a reality $C$ that is owned or used by consumer $\mathrm{B}$, the change being effected by service provider $A$ at the request of $B$, and in many cases in collaboration with him / her, but without leading to the production of a good that can circulate in the economy independently of medium C". In other words, Gadrey introduced services as a process or a set of processing operations that are implemented through interactions (i.e., the intervention of $\mathrm{B}$ on $\mathrm{C}$, the intervention of $\mathrm{A}$ on $\mathrm{C}$, and service relations or interactions) between three main elements: service provider, client, and a reality to be transformed. The medium $\mathrm{C}$ in Gadrey's definition may be material objects (M), information (I), knowledge $(\mathrm{K})$, or individuals (R). An important point in Gadrey's definition compared to Hill's is that the output cannot circulate economically and independently from C.

Inspired by Lancaster (1966) and Saviotti and Metcalfe (1984), Gallouj and Weinstein (1997) developed a conceptual framework for the provision of products (i.e., goods and services) that describe service output in terms of a set of characteristics and competences, 


\title{
Innovation in Services: A Literature Review
}

\author{
Rabeh Morrar
}

which reflects both the internal structure of products and external properties. The delivery of services in this framework depends on the simultaneous mobilization of competences (from service provider and clients) and (tangible or intangible) technical characteristics. In a more detailed description, the service provision may require the interactions between four main vectors: service provider competencies [C], consumers' competencies $\left[\mathrm{C}^{*}\right]$, tangible and intangible technical characteristics $[\mathrm{T}]$, and finally, the vector of characteristics of final service output $[\mathrm{Y}]$. This framework has been used in a large extent to define innovation in service within the synthesis approach, which is discussed later in this article.

One of the most well-known conceptualizations of services in the last decade is the service-dominant logic by Vargo and Lusch (2004). Their approach was to redress the model of exchange in marketing, which had a dominant logic based on the exchange of "goods", which are mainly manufactured outputs. In the new marketingdominant logic, service provision rather than goods is fundamental to economic exchange.

The main proposition of service-dominant logic is that:

"...organizations, markets, and society are fundamentally concerned with exchange of service - the applications of competences (knowledge and skills) for the benefit of a party. That is, service is exchanged for service; all firms are service firms; all markets are centered on the exchange of service, and all economies and societies are service based. Consequently, marketing thought and practice should be grounded in service logic, principles, and theories" (Lusch \& Vargo, 2004).

Thus, the service-dominant logic highlights the role of producer and consumer in the production of a service (i.e., value is co-created).

In similar work, Grönroos (2006) makes a comparison between service logic and good logic. He found that service logic best fits the context of most goods-producing businesses today. Goods are one of several types of resources functioning in a service-like process, and it is this process that is the service that customers consume.

Four main criteria, commonly referred to as the "IHIP criteria", have been used to distinguish services from products: intangibility, heterogeneity, inseparability, and perishability (Fisk et al., 1993). Services are considered intangible because, unlike products, they can- not be perceived physically nor can the results be fully preconceived by the customer before delivery (Biege et al. 2013). In other words, service products and processes are characterized by a "fuzzy", information-rich, and intangible nature, which means that they are not embedded in material or physical structures. Heterogeneity describes the variability of the results when providing services. Inseparability refers to the simultaneous provision and consumption of services; the customer is a co-producer and has to be included in the processes of both providing and consuming a service. Finally, perishability refers to "the transitory nature of services since these cannot be kept, stored for later utilization, resold, or returned" (Biege et al. 2013).

As mentioned earlier, a clear definition of services promotes understanding of service innovation. Due to the IHIP criteria, the dichotomy, or classification, of innovation into product and process innovation is not easy to apply to services in comparison with that in the manufacturing sector. For example, inseparability or co-terminality blurs the dividing line between product and process innovation (Bitran \& Pedrosa, 1998). And, it highlights the role of clients in service innovation. The client plays an important role in the development of new services (Kline \& Rosenberg, 1986; De Brentani, 2001). In any service innovation, feedback provided through the consumers of services is an important source of incremental service innovation (Riedl et al., 2008). In manufacturing, conversely, the clients are independent of the production process; they are just users of final products, and they do not participate in the production and delivery of the product.

The intangibility of services confirms the key role that information technology plays in innovation activities in services (Sirilli \& Evangelista, 1998). However, the intangibility of service products hinder the measurement of the service output. Some scholars (Gallouj \& Weinstein, 1997; Windrum \& Garcia-Goni, 2008) have tried to overcome the ill-defined nature of service outputs by developing a new approach that is applicable to both tangible and intangible products. This integrative approach is discussed later in this article.

The low levels of capital equipment used in many services indicate that the technological competences and physical capital that play a major role in the production of industrial goods are less consistent with the "fuzzy" or immaterial outputs of services. Service firms are considered to be rather highly dependent on competences embedded in human capital as a key competitive factor 


\section{Innovation in Services: A Literature Review}

\section{Rabeh Morrar}

and strategic element in the organization and delivery of service products (Sirilli \& Evangelista, 1998). Thus, services may need special innovation that is not dependent on physical artifacts or complex technological changes (i.e., formalized R\&D) or modes in which training activities and organizational changes are central dimensions of the innovation process (Castellacci, 2006).

\section{Conceptual Perspectives for Innovation in Service}

Service innovation studies have tried to go beyond the manufacturing-based perspective (e.g., Gallouj; 2002; Gallouj \& Weinstein 1997). They have sought to address the peculiarities of service activities in terms of innovation. In this view, the service-based approach (Gallouj, 1994) and integrative approach (Gallouj \& Weinstein, 1997) are considered two prominent conceptualization frameworks that extend beyond the traditional perspective, which is represented by the assimilation approach. Table 1 summarizes the three conceptual approaches to innovation in services: assimilation, demarcation, and integration.

\section{Assimilation}

In the assimilation approach, innovation in services is perceived as fundamentally similar to innovation in manufacturing. This traditional approach to innovation in services only considers technological or visible modes of product and process innovation. It ignores other non-technological or invisible modes of innovation, which are likely to include several types of innovation-like "social innovations, organizational innovations, methodological innovations, marketing innovations, innovations involving intangible products or processes, etc." (Djellal \& Gallouj, 2010b). Therefore, the assimilation approach underestimates innovation in service activities, which is characterized by its intangible (invisible) and information-based nature.

The theoretical and empirical works favoring an assimilation approach are the most numerous. Within this perspective, Barras' reverse product lifecycle (Barras, 1986) is one of the most prominent works devoted to the adoption of information and communication technologies in service activities and their effects on innovation. The reverse product lifecycle, in contrast to the tradi-

Table 1. Conceptual perspective for innovation in services

\begin{tabular}{|c|c|c|c|}
\hline $\begin{array}{l}\text { Theoretical } \\
\text { Perspective }\end{array}$ & Assimilation & Demarcation & Integration \\
\hline Type of innovation & - technological & - non-technological & $\begin{array}{l}\text { - complex } \\
\text { - architectural }\end{array}$ \\
\hline $\begin{array}{l}\text { Characteristics of } \\
\text { innovation }\end{array}$ & $\begin{array}{l}\text { - equates or reduces } \\
\text { innovation in services to the } \\
\text { adoption and use of } \\
\text { technology } \\
\text { - considers technological or } \\
\text { visible modes of product and } \\
\text { process innovation }\end{array}$ & $\begin{array}{l}\text { - leads to new typologies for } \\
\text { innovation in services: non- } \\
\text { technological types of } \\
\text { innovation such } \\
\text { organizational innovation, } \\
\text { ad-hoc innovation, and } \\
\text { marketing innovation }\end{array}$ & $\begin{array}{l}\text { - shows convergence between } \\
\text { manufactured goods and } \\
\text { services in regards of } \\
\text { innovation } \\
\text { - includes technological and } \\
\text { non-technological } \\
\text { innovation }\end{array}$ \\
\hline $\begin{array}{l}\text { Innovation } \\
\text { framework }\end{array}$ & $\begin{array}{l}\text { - attempts to assimilate } \\
\text { services within the } \\
\text { consolidated framework } \\
\text { used for manufacturing } \\
\text { sectors and manufactured } \\
\text { products }\end{array}$ & $\begin{array}{l}\text { - attempts to develop a } \\
\text { specific framework for } \\
\text { service innovation, while } \\
\text { attempting to highlight all } \\
\text { the specificities in service } \\
\text { product and production } \\
\text { processes }\end{array}$ & $\begin{array}{l}\text { - attempts to develop a } \\
\text { common conceptual } \\
\text { framework, able to account } \\
\text { for an enlarged view of } \\
\text { innovation that is applicable } \\
\text { to any tangible or intangible } \\
\text { product } \\
\text { - proposes a new taxonomy of } \\
\text { innovation in services based } \\
\text { on a new definition of } \\
\text { product }\end{array}$ \\
\hline
\end{tabular}




\section{Innovation in Services: A Literature Review}

\section{Rabeh Morrar}

tional product lifecycle model (Abernathy \& Utterback, 1975), starts with the introduction of incremental process innovations that aim to improve the efficiency of the service produced. In the second phase, more radical process innovations are implemented to improve the quality of services. In the final phase, new product innovations are produced.

Another important illustration of the assimilation approach is provided by the construction of new evolutionary taxonomies for innovation in services, which emphasize different trajectories for different groups of activities according to their technological intensive aspect (Evangelista, 2000; Miozzo \& Soete, 2001; Soete \& Miozzo, 1989). Soete and Miozzo's taxonomy (1989) distinguishes the following trajectories: supplier-dominated, scale-intensive, science-based, information intensive, and specialized suppliers.

Innovation systems and networks are also other important concepts for discussing the innovation activities in an interactive and dynamic process (Edquist 1997; Lundvall, 1992; Manley, 2002; Nelson, 1993). These innovation networks also reflect a technology bias when they address service innovation.

\section{Demarcation}

The demarcation approach considers that it is inappropriate to study service innovation activities by only mobilizing conceptual and empirical tools that are mainly developed for technical-based activities (e.g., R\&D, patents, and accumulation of capital). In Gallouj and Savona's (2009) natural lifecycle of theoretical concern, the assimilation approach represents the maturity phase.

The demarcation perspective seeks to consider any specific characteristics of the nature and modes of organization of innovation in services (Gallouj \& Savona, 2009), and it emphasizes the importance of service trajectories, taking into account the characteristics of service output (i.e., immateriality, interactivity, and co-production). It focuses on non-technological (service-based) and invisible innovation output (e.g., service customization, problem solving, new solutions, new methods, and new organizational structures). These innovation activities contribute to the economic development.

The demarcation approach leads to the production of new typologies for innovation in services; these typologies are innovation indicators dedicated to services that include non-technological types of innovation such as organizational innovation, ad-hoc innovation, and marketing innovation. For example, Gadrey and Gallouj (1998) developed a new topology for consultancy that breaks down the product/process technological taxonomy for service innovation and includes three service specific types of innovation: ad-hoc innovation, new-expertise fields of innovation, and formalization innovation. McCabe (2000) has focused on organizational innovation (e.g., work organizations and standardized methods of management control) in financial services. In similar work, Van der Aa and Elfring (2002) developed a taxonomy of three modes of organization innovation: multi-unit organizations, new combinations of services, and customers as co-producers.

\section{Integration}

The integrative, or synthesizing, approach aggregates both the assimilation and demarcation approaches within a common conceptual framework that enlarges the view of innovation. This new perspective encompasses both services and goods and technological and non-technological modes of innovation (Gallouj \& Savona, 2009; Gallouj \& Windrum, 2009). It represents the emerging and expanding phase of the natural lifecycle of theoretical development in the service innovation discussion. The most important contribution in the integrative approach is provided by Gallouj and Weinstein (1997), who apply a characteristics-based representation to the product. As mentioned earlier, in such a representation, the product is represented by four main vectors, and "innovation can be defined accordingly as the changes affecting one or more elements of one or more vectors of characteristics (both technical and service) or of competences" (Gallouj \& Savona, 2009).

The importance of the synthesis framework is also associated with the fact that the boundaries between goods and services have become blurred. This framework is motivated by the convergence between service and manufacturing, where the distinction between innovation in services and manufacturing is becoming more difficult due to the service dynamic and innovation blurring. In this new context, two main changes are taking place: manufacturing is becoming more like services and services are becoming more like manufacturing. In the former case, manufacturing firms produce more service products related to the main industrial products, and therefore, higher portions of their turnovers are becoming achieved through selling services (Howells, 2006). This process is summed up as the "servitization" of the manufacturing 


\section{Innovation in Services: A Literature Review}

\section{Rabeh Morrar}

industry (Quinn et al., 1990). In the latter case, services firms become more innovative and greater parts of their innovative output are reflected by the traditional technological innovation in manufacturing. In other words, "services become more manufacturing-like in innovation" (Howells, 2006). Therefore, the synthesis framework is required to "redefine the product in such a way that it offers a relatively solid framework to generalize a theory of innovation for material and immaterial product" (Gallouj \& Savona, 2009). The synthesis approach "highlights the increasing complex and multidimensional character of modern services and manufacturing, including the increasing bundling of services and manufacturing into solutions" (Salter \& Tether, 2006).

The integrative approach is broadly used in the recent literature of innovation in services. In recent years, most of the conceptual frameworks and empirical tests addressing innovation in services apply an integrative approach in which both technological and non-technological innovation are emphasized (Gebauer, 2008; Hipp et al., 2000; Tidd, 2006; Ulaga \& Reinartz, 2011).

\section{Service Innovation and Economic Performance}

In a service economy, defining and identifying the whole range of innovation is not easy, and it requires us to go beyond the assimilation, technology-biased perspective. Anyhow, in services as in manufacturing, innovation is a major source of economic performance. However, the link between innovation in services and economic variables such as productivity should be clarified. Indeed, in the service economy, the innovation gap is associated with a performance gap.

\section{Innovations in services and productivity}

Conceptually, there is no specific answer to the question of the degree and sign of the relationship between innovation in services and productivity, but it is related to the service specificities that "influence the definition and measurement of productivity" (Djellal \& Gallouj, 2009).

The use of a technological or industrial approach for measuring innovation activities in services will lead to the under-estimation of both innovation and economic performance. And, it will lead to two gaps: an innovation gap and a performance gap (Djellal \& Gallouj, 2010a). According to Djellal and Gallouj (2010b), "the innovation gap indicates that our economies contain invisible or hidden innovations that are not captured by the traditional indicators of innovation, while the performance gap is reflected in an underestimation of the efforts directed towards improving performance (or certain forms of performance) in those economies".

Measuring the productivity of immaterial and non technology-based services might need different methods from those employed to measure the productivity of material and technical activities in the manufacturing sector. For example, Biege and colleagues (2013) denoted that characteristic features of services were detected as reasons for the gap in measuring productivity in services. In addition to IHIP, Biege underlined four requirements when measuring productivity in services:

1. The innovativeness of the output has to be included to adequately measure productivity in knowledge-intensive business services. Innovativeness is measured by differentiating "services new to the company" from "services new to the market".

2. The "internal output of a service process has to be included to adequately measure service productivity.

3. Input figures in productivity measurement concepts for innovative services have to include interactive inputs that are not expressed by provider's and customer's inputs, especially time and cost induced by interactive loops in service processes mainly in knowledge-intensive business services.

4. Knowledge, competencies, and skills are central resources in many services, and they should be included in a productivity measurement concept.

Corsten (1994) measured service productivity based on an approach from production theory, which consists of factor combinations between inputs and corresponding outputs. In other words, service productivity is measured using multiple stages of a service delivery process.

Johnston and Jones (2004) proposed two perspectives for measuring service productivity: i) operational productivity, which is measured by the ratio of operational outputs to inputs of a period of time, and ii) customer productivity, which is measured by the ratio of customer output, such as experience and outcome, to value-tocustomer inputs, such as time, effort, and costs.

\section{Effect of service innovation on employment}

The relationship between innovation and employment has been the subject of abundant literature. This de- 


\section{Innovation in Services: A Literature Review}

\section{Rabeh Morrar}

bate originated in manufacturing sector to analyze the effect of technological change on employment (Freeman \& Soete, 1987; Hicks,1973; Pasinetti, 1981). In this context, two counter-arguments are put forth. The first argument anticipates a reduction in employment due to technological advancement. The second argument assumes that market-compensation mechanisms are able to overcome the negative effect on employment caused by labour-saving process innovation (Vivarelli, 2007; Vivarelli \& Pianta, 2000).

In services, the technological trajectories are not the main form of innovation. Innovation activities include other non-technological elements. Therefore, the product/process dichotomy in the analysis of the effect on employment is not always consistent with service sector. The employment debate in the manufacturing sector is unlikely to sufficiently explain the effect on employment by non-technological forms of innovation in services. For example, new market strategies make important changes to consumer preferences and increase the market demands for new services, which in turn affect the employment rate. In addition, some of the compensation mechanisms (e.g., lower prices, new investments, and new machines) in manufacturing industries cannot always be applied directly to services. For example, because of the immateriality and co-productivity of many service outputs, it is not always easy to fix their prices and measure their intangible investment. In many services, there is an overlap between types of innovation, and it is not easy to disentangle them and distinguish labour-saving from labour-using effects.

Consequently, new methodological and conceptual frameworks might be needed to explain the employment effect of immaterial and invisible activities beyond the product/process dichotomy. New proxies are needed, provided that they are developed on the basis of the industrial sector, such as R\&D and patents. In addition, new compensation and contradictory mechanisms need to be envisaged. These new mechanisms must challenge the manufacturing sector's traditional views that product innovation has a labour-using effect and that process innovation has a labour-saving effect.

\section{Conclusion}

In this article, the literature on innovation in services was reviewed using the assimilation-differentiation-integration framework. In addition to the discussion of the service concept, we emphasized the importance of both demarcation and integrative approaches as im- portant tools to focus on non-technological aspects of service innovation, which were previously ignored due to the application of an assimilation view for innovation in service sectors. Also, recent studies show the integrative approach is found to be the most promising and comprehensive theoretical perspective that is employed to discuss innovation in service sectors. The relationship between innovation in services and economic performance were discussed using productivity and employment as two important indicators for economic performance.

This article has sought to provide an extensive and multifaceted review of the research on innovation in services over the last two decades. Its aim is to generate more achievable policy implications for how innovation in the service sector should be discussed in an integrative approach in order to reveal the vital role that innovation in services might play in modern economies. This literature review opens further discussion about new issues in innovation in services, such as innovation networks in services - mainly public-private innovation networks, social innovation, and entrepreneurship in the service sector.

\section{About the Author}

Rabeh Morrar is an Assistant Professor of Innovation Economics at An-Najah National University in Nablus, Palestine. Rabeh's doctoral dissertation from Lille 1 University in France focused on publicprivate innovation networks in the service sector, and his current research is focused on innovation in the service sector, $R \& D$ management, and technology management. Rabeh is also CEO of BEST, a small business in Palestine that provides innovation solutions and training.

\section{References}

Barras, R. 1986. Towards a Theory of Innovation in Services. Research Policy, 15(4): 161-173.

http://dx.doi.org/10.1016/0048-7333(86)90012-0

Biege, S., Lay, G., Zanker, C., \& Schmall, T. 2013. Challenges of Measuring Service Productivity in Innovative, Knowledge-Intensive Business Services. The Service Industries Journal, 33(3-4): 378-391. http://dx.doi.org/10.1080/02642069.2013.747514

Bitran, G. \& Pedrosa, L. 1998. A Structured Product Development Perspective for Service Operations. European Management Journal, 16(2): 169-189.

http://dx.doi.org/10.1016/S0263-2373(97)00086-8 


\section{Innovation in Services: A Literature Review}

\section{Rabeh Morrar}

Castellacci, F. 2006. Innovation and the International Competitiveness of Manufacturing and Service Industries. Brussels: DIME Network of Excellence.

De Brentani, U. 2001. Innovative Versus Incremental New Business Services: Different Keys for Achieving Success. Journal of Product Innovation Management, 18(3): 169-187. http://dx.doi.org/10.1111/1540-5885.1830169

Djellal, F. \& Gallouj, F. 2009. Measuring and Improving Productivity in Services: Issues, Strategies and Challenges. Cheltenham, UK: Edward Elgar Publishing.

Djellal, F. \& Gallouj, F. 2010a. The Innovation Gap and the Performance Gap in the Service Economies: A Problem for Public Policy. In F. Gallouj \& F. Djellal (Eds.), The Handbook of Innovation and Services: 653-676. Cheltenham, UK: Edward Elgar Publishing.

Djellal, F. \& Gallouj, F. 2010b. Services, Innovation and Performance: General Presentation. Journal of Innovation Economics \& Management, 5(1): 5-5.

http://dx.doi.org/10.3917/jie.005.0005

DTI. 2007. Innovation in Services. Occasional Paper No. 9. London: Department of Trade and Industry.

Edquist, C. 2012. Systems of Innovation: Technologies, Institutions and Organizations. London: Routledge.

Evangelista, R. 2000. Sectoral Patterns of Technological Change in Services. Economics of Innovation and New Technology, 9(3): 183-222. http://dx.doi.org/10.1080/10438590000000008

Fisk, R. P., Brown, S. W., \& Bitner, M. J. 1993. Tracking the Evolution of the Services Marketing Literature. Journal of Retailing, 69(1): 61-103.

http://dx.doi/org/10.1016/S0022-4359(05)80004-1

Freeman, C. P. \& Soete, L. 1987. Technical Change and Full Employment. New York: Blackwell Publishers.

Fuchs, V. R. 1968. The Service Economy. New York: Columbia University Press.

Gadrey, J. 2000. The Characterization of Goods and Services: An Alternative Approach. Review of Income and Wealth, 46(3): 369-387. http://dx.doi.org/10.1111/j.1475-4991.2000.tb00848.x

Gadrey, J. \& Gallouj, F. 1998. The Provider-Customer Interface in Business and Professional Services. The Service Industries Journal, 18(2): 01-15.

http://dx.doi.org/10.1080/02642069800000016

Gallouj, F. 1994. Économie de l'innovation dans les services. Paris: L'Harmattan.

Gallouj, F. 1998. Innovating in Reverse: Services and the Reverse Product Cycle. European Journal of Innovation Management, 1(3): 123-138.

http://dx.doi.org/10.1108/14601069810230207

Gallouj, F. 2002. Innovation in the Service Economy: The New Wealth of Nations. Cheltenham, UK: Edward Elgar Publishing.

Gallouj, F. \& Savona, M. 2009. Innovation in Services: A Review of the Debate and a Research Agenda. Journal of Evolutionary Economics, 19(2): 149-172.

http://dx.doi.org/10.1007/s00191-008-0126-4

Gallouj, F. \& Weinstein, O. 1997. Innovation in Services. Research Policy, 26(4-5): 537-556.

http://dx.doi.org/10.1016/S0048-7333(97)00030-9
Gallouj, F. \& Windrum, P. 2009. Services and Services Innovation. Journal of Evolutionary Economics, 19(2): 141-148.

http://dx.doi.org/10.1007/s00191-008-0123-7

Gebauer, H. 2008. Identifying Service Strategies in Product Manufacturing Companies by Exploring Environment-Strategy Configurations. Industrial Marketing Management, 37(3): 278-291. http://dx.doi.org/10.1016/j.indmarman.2007.05.018

Grönroos, C. 2006. Adopting a Service Logic for Marketing. Marketing Theory, 6(3): 317-333.

http://dx.doi.org/0.1177/1470593106066794

Hicks, J. R. 1987. Capital and Time: A Neo-Austrian Theory. Oxford University Press.

Hill, T. P. 1977. On Goods and Services. Review of Income and Wealth, 23(4): 315-338. http://dx.doi.org/10.1111/j.1475-4991.1977.tb00021.x

Hipp, C., Tether, B. S., \& Miles, I. 2000. The Incidence and Effects of Innovation in Services: Evidence from Germany. International Journal of Innovation Management, 4(4): 417-453. http://dx.doi.org/10.1142/S1363919600000226

Howells, J. 2006. Intermediation and the Role of Intermediaries in Innovation. Research Policy, 35(5): 715-728. http://dx.doi.org/10.1016/j.respol.2006.03.005

Johnston, R. \& Jones, P. 2004. Service Productivity: Towards Understanding the Relationship between Operational and Customer Productivity. International Journal of Productivity and Performance Management, 53(3): 201-213. http://dx.doi.org/10.1108/17410400410523756

Kline, S. J. \& Rosenberg, N. 1986. An Overview of Innovation. In R. Landau \& N. Rosenberg (Eds.), The Positive Sum Strategy: Harnessing Technology for Economic Growth: 275-305. Washington, D.C.: National Academy Press.

Lancaster, K. J. 1966. A New Approach to Consumer Theory. Journal of Political Economy, 74(2): 132-157. http://www.jstor.org/stable/1828835

Lundvall, B.-Å. 1992. National Systems of Innovation: Towards a Theory of Innovation and Interactive learning. London: Pinter Publishers.

Lusch, R. F. \& Vargo, S. L. 2014. Service-Dominant Logic: Premises, Perspectives, Possibilities. Cambridge University Press.

Manley, K. 2007. The Systems Approach to Innovation Studies. Australasian Journal of Information Systems, 9(2): 91-102. http://dx.doi.org/10.3127/ajis.v9i2.196

Mccabe, D. 2000. The Swings and Roundabouts of Innovating for Quality in UK Financial Services. The Service Industries Journal, 20(4): 01-20.

http://dx.doi.org/10.1080/02642060000000043

Melvin, J. R. 1995. History and Measurement in the Service Sector: A Review. Review of Income and Wealth, 41(4): 481-494. http://dx.doi.org/10.1111/j.1475-4991.1995.tb00140.x

Miozzo, M. \& Soete, L. 2001. Internationalization of Services - A Technological Perspective. Technological Forecasting and Social Change, 67(2): 159-185. http://dx.doi.org/10.1016/S00401625(00)00091-3

Nelson, R. 1993. National Innovation Systems: A Comparative Analysis. Oxford University Press. 


\section{Innovation in Services: A Literature Review}

\section{Rabeh Morrar}

OECD. 2005. Growth in Services: Fostering Employment, Productivity and Innovation. Paris: Organisation for Economic Co-operation and Development.

Pasinetti, L. L. 1983. Structural Change and Economic Growth: A Theoretical Essay on the Dynamics of the Wealth of Nations. Cambridge University Press.

Quinn, J. B., Doorley, T. L., \& Paquette, P. C. 1990. Technology in Services: Rethinking Strategic Focus. MIT Sloan Management Review, 1990(Winter).

Riedl, C., Böhmann, T., Rosemann, M., \& Krcmar, H. 2008. Quality Aspects in Service Ecosystems: Areas for Exploitation and Exploration. Proceedings of the 10th International Conference on Electronic Commerce: 19.1-19.7. New York: Association for Computing Machinery (ACM)

http://dx.doi.org/10.1145/1409540.1409566

Salter, A. \& Tether, B. S. 2006. Innovation in Services: Through the Looking Glass of Innovation Studies. Background paper for the AIM Grand Challenge on Service Science, Oxford.

Saviotti, P. P. \& Metcalfe, J. S. 1984. A Theoretical Approach to the Construction of Technological Output Indicators. Research Policy, 13(3): 141-151.

http://dx.doi.org/10.1016/0048-7333(84)90022-2

Say, J. B. 1855. A Treatise on Political Economy; Or the Production, Distribution, and Consumption of Wealth. Philadelphia: Lippincott, Grambo \& Co.

Singelmann, J. 1978. The Sectoral Transformation of the Labor Force in Seven Industrialized Countries, 1920-1970. American Journal of Sociology, 83(5): 1224-1234.

http://www.jstor.org/stable/2778192

Sirilli, G. \& Evangelista, R. 1998. Technological Innovation in Services and Manufacturing: Results from Italian Surveys. Research Policy, 27(9): 881-899.

http://dx.doi.org/10.1016/S0048-7333(98)00084-5

Smith, A. \& Skinner, A. 1982. The Wealth of Nations: Books I-III. London; New York: Penguin Classics.

Soete, L. \& Miozzo, M. 1989. Trade and Development in Services: A Technological Perspective. Maastricht, The Netherlands: Maastricht Economic Research Institute on Innovation and Technology.
Stanback, T. M. J. 1979. Understanding the Service Economy. Johns Hopkins University Press.

Suchitra, P. 2013. Building Multi-Skills Based Talent Management. IOSR Journal of Business and Management, 15(2): 1-3. http://dx.doi.org/10.9790/487X-1520103

Sundbo, J. \& Gallouj, F. 1999. Innovation in Services in Seven European Countries: The Result of Work Package 3-4 of the SI4S Project. Roskilde, Denmark: Forskningsrapport / Center for Servicestudier, Roskilde Universitetscenter.

Tether, B. S. 2005. Do Services Innovate (Differently)? Insights from the European Innobarometer Survey. Industry \& Innovation, 12(2): 153-184. http://dx.doi.org/10.1080/13662710500087891

Tidd, J. 2006. Innovation Models. London: Imperial College London.

Ulaga, W. \& Reinartz, W. J. 2011. Hybrid Offerings: How Manufacturing Firms Combine Goods and Services Successfully. Journal of Marketing, 75(6): 5-23. http://dx.doi.org/10.1509/jm.09.0395

Utterback, J. M. \& Abernathy, W. J. 1975. A Dynamic Model of Process and Product Innovation. Omega, 3(6): 639-656. http://dx.doi.org/10.1016/0305-0483(75)90068-7

Van der Aa, W., \& Elfring, T. 2002. Realizing Innovation in Services. Scandinavian Journal of Management, 18(2): 155-171. http://dx.doi.org/10.1016/S0956-5221(00)00040-3

Vargo, S. L. \& Lusch, R. F. 2004. Evolving to a New Dominant Logic for Marketing. Journal of Marketing, 68(1): 1-17. http://www.jstor.org/stable/30161971

Vivarelli, M. 2007. Innovation and Employment: A Survey. Discussion Paper No. 2621:22. Institute for the Study of Labor.

Vivarelli, M. \& Pianta, M. 2000. The Employment Impact of Innovation: Evidence and Policy. London: Routledge.

Windrum, P. \& García-Goñi, M. 2008. A Neo-Schumpeterian Model of Health Services Innovation. Research Policy, 37(4): 649-672. http://dx.doi.org/10.1016/j.respol.2007.12.011 